\title{
THE BOUNDARIES TO DIALOGUE WITH THE EUROPEAN COURT OF HUMAN RIGHTS
}

Lize R. Glas (assistant professor of European law, Radboud University, the Netherlands, l.glas@jur.ru.nl)

Forthcoming in: W. Benedek, P. Czech, L. Heschl, K. Lukas and M. Nowak (eds.), European Yearbook on Human Rights 2018 (Intersentia, 2018).

KEYWORDS: European Court of Human Rights, European Convention on Human Rights, dialogue, Protocol 16 ECHR, good faith, take into account, res interpretata, interpretive authority, Austria, Belgium, Germany, Iceland, Italy, Latvia, the Netherlands, Russia, Spain, the United Kingdom.

\begin{abstract}
This contribution aims to answer the question which legal boundaries are applicable when domestic courts engage in a dialogue with the ECtHR about a Strasbourg judgment. This question is answered from an international legal perspective, i.e. the perspective of the ECtHR, and the perspective of eleven domestic legal orders. Where possible, this contribution will comment on the practical significance of the legal boundaries found, so as to put their significance into perspective.
\end{abstract}

\section{INTRODUCTION}

The States Parties to the European Convention on Human Rights (ECHR) have invited the European Court of Human Rights (ECtHR) to 'deepen' its dialogue with the highest national courts 'further'. ${ }^{1}$ For the ECtHR, dialogue is a 'high priority' as well. ${ }^{2}$ Dialogue has been on the agenda of the ECtHR and the States for some years ${ }^{3}$ and, therefore, has turned out to be more than just a fashionable buzzword; it is here to stay. The States Parties have even drafted a 'Protocol of Dialogue' ${ }^{4}$ to the ECHR. This optional protocol will enable the highest domestic judges to request the ECtHR to give an advisory opinion on questions of principle relating to the ECHR. ${ }^{5}$ The requesting court should present inter alia a 'statement of its own views on the question, ${ }^{6}$ and decides itself 'on the effects of the advisory opinion in the domestic proceedings'. ${ }^{7}$ The Protocol thus makes it possible for the domestic and European judges to

\footnotetext{
${ }^{1}$ Brussels Declaration (2015), para. A(1)(b); See also: Brighton Declaration (2012), para. 12(c); Draft Copenhagen Declaration (2018), para. 31.

${ }^{2}$ ECTHR, ‘Annual Report 2017’, p. 9; See also: ECTHR, ‘Annual Report 2016’, p. 16.

${ }^{3}$ See for examples: L.R. GLAs, The Theory, Potential and Practice of Procedural Dialogue in the European Convention on Human Rights System, Intersentia, Antwerp 2016, pp. 129-133.

${ }^{4}$ D. SPIElmanN, 'Opening Speech’, Strasbourg, 31.01.2014.

${ }^{5}$ Articles 1(1) and 5 Protocol 16 ECHR.

${ }^{6}$ Explanatory Report to Protocol 16 ECHR, para. 12 (provided this is 'possible and appropriate'); Article 1(1) Protocol 16 ECHR.

${ }^{7}$ Explanatory Report to Protocol 16 ECHR, para. 25; This is possible because the advisory opinions are not binding, see: Article 5 Protocol 16 ECHR.
} 
respond to each other. The appeal of engaging in a dialogue with the ECtHR is clear: it facilitates that domestic judges can explain to the ECtHR how their legal system works and why they make certain choices within their specific domestic context. Dialogue can, thus, contribute to the smooth cooperation between the ECtHR and the domestic judges. ${ }^{8}$ Nevertheless, not every instance of dialogue has been equally eagerly applauded. When the Supreme Court of the United Kingdom (UK) declined to follow the Chamber judgment in the case of Al-Khawaja and Tahery v. the UK 'so that there takes place what may prove to be a valuable dialogue', ${ }^{9}$ the Strasbourg judges welcomed that decision in the Grand Chamber judgment in the same case. ${ }^{10}$ The Russian Constitutional Court, referring to inter alia its British counterpart, has also objected to Strasbourg judgments, 'proceeding form the need of constructive interaction and mutually respectful dialogue'. ${ }^{11}$ When the right to object to a Strasbourg judgment was subsequently laid down in a law, ${ }^{12}$ Russia did not receive applause. On the contrary, the Venice Commission concluded that the law 'prevents dialogue' and that Russia 'should have recourse to dialogue, instead of resorting to unilateral measures'. ${ }^{13}$ Apparently, the British judges have not crossed a boundary, while the Russians have, even though they both say they want to engage in a dialogue.

Against the background just sketched, this contribution aims to answer the question which legal boundaries are applicable when domestic courts engage in a dialogue with the ECtHR about a Strasbourg judgment. The answer depends on one's perspective, as is illustrated by the contrasting views of the Russian Constitutional Court and the Venice Commission. More specifically, the answer depends on whether it is approached from the ECtHR's perspective or that of the State Parties, because the former looks through the lens of international law, including the ECHR, whilst the relations of the latter 'to the ECtHR are primarily determined by their national constitutions and national laws' ${ }^{14}$ Therefore, the question that this contribution sets out to answer is answered from different perspectives: the international legal perspective (in section 2), i.e. the perspective of the ECtHR, and the perspective of eleven domestic legal orders (in section 3). These domestic legal orders have been selected to include both predominantly monist ${ }^{15}$ and dualist systems; ${ }^{16}$ and systems in which the ECHR has a different

\footnotetext{
${ }^{8}$ See more elaborately: L.R. GLAS, 'Dialogue in the European Convention on Human Rights System: inspiration, added-value and means', (2015) European Journal of Human Rights, 258-260.

${ }^{9} R$ v. Horncastle \& Others [2009] UKSC 14, para. 11.

${ }^{10}$ Al-Khawaja and Tahery v. UK (GC), Nos. 26766/05 and 22228/06, 15.12.2001, Concurring opinion of judge Bratza, para. 2 and Joint partly dissenting and partly concurring opinion of Judges Sajó and Karakaş.

${ }^{11}$ Venice Commission, 'Final Opinion on the Amendments to the Federal Constitutional Law of the Constitutional Court', No. 832/2015, CDL-AD(2016)016, 13.06.2016, Appendix, para. 72, referring to judgment No. 21-П/2015, 14.07.2015.

${ }^{12}$ See also: section 3.8 .

${ }^{13}$ Venice COMmission, supra note 11, Appendix, paras. 136, 146.

${ }^{14}$ B. PETERS, 'The Rule of Law Effects of Dialogues between National Courts and Strasbourg: An Outline' in A. NOLLKAEMPER and M. KANETAKE (eds.), The rule of law at the national and international levels: contestations and deference, Hart Publishing, Oxford and Portland 2016, p. 206.

${ }^{15}$ E.g. Germany, the Netherlands and Spain, see: W. CzAPLinsKi, 'International Law and Polish Municipal Law. A Case Study’ (1995) 8 Hague Yearbook of International Law, 35.

${ }^{16}$ E.g. Italy, UK and Iceland, see: idem.
} 
status. ${ }^{17}$ Additionally, domestic legal orders in which the judges have elaborated on the boundaries to dialogue with the ECtHR have been included. ${ }^{18}$ Where possible, this contribution will comment on the practical significance of the legal boundaries found, so as to put their significance into perspective. This contribution, in sum, engages in doctrinal research, as it sets out to describe and analyse the applicable legal rules. ${ }^{19}$ Additionally, it undertakes a comparative exercise, both horizontally, by comparing the domestic rules with each other (in section 3.12), and, vertically, by comparing the domestic rules with the international rules (in section 4).

Answering the question from different perspectives will, as just described, make it possible to compare the domestic perspectives with each other and to compare the domestic perspectives with the international legal perspective. The latter comparison helps gain insight into whether the ECtHR and the domestic judges agree on the legal boundaries that apply to the dialogue between them. If this would not be the case, they arguably do not speak the 'same language', something that may prove to be a bar to a fruitful dialogue. Considering the widespread agreement about the desirability of dialogue, it is important to conduct research into potential bars to a dialogue. Research into the boundaries to dialogue with the ECtHR is also important, because, in practice, this court, like other courts, can only encourage domestic authorities 'to listen, but not [force them] to act'. ${ }^{20}$ Moreover, unlike some other courts, the ECtHR does not have the power to reverse judgments of the courts that it reviews, to invalidate legislation or to impose punitive sanctions. Therefore, room for disagreement with Strasbourg and inaction after it has adopted a judgment is particularly broad. Considering this reality, it is important to clarify that there indeed exist legal boundaries to the dialogue.

The limitations of this contribution are fourfold. First, the contribution addresses dialogue between the ECtHR and the domestic courts, i.e. judicial dialogue, and, therefore, does not focus on other domestic actors. This choice has been made, because most abstractly defined boundaries that originate from the domestic legal systems have been formulated by domestic judges, for domestic judges ${ }^{21}$ and because these judges are the 'main interlocutors' of the ECtHR. ${ }^{22}$ Nevertheless, section 2 mainly uses the term States, because this is the terminology of the EC(t)HR. The boundaries that apply to the States also apply to domestic judges, since the 'duty in international law to comply with the requirements of the Convention may require action to be taken by any State authority'. ${ }^{23}$ Second, the 'sample' of the research is limited: the domestic perspectives are researched based on 11 domestic legal systems, while there are

\footnotetext{
${ }^{17}$ Constitutional status (e.g. Austria and the Netherlands), ‘super-legislative ranking' (e.g. Belgium and Spain), 'legislative ranking' (e.g. Italy and Germany), see: G. MARTINICO, 'Is the European Convention Going to Be 'Supreme’? A Comparative-Constitutional Overview of ECHR and EU Law before National Courts’ (2012) 23 The European Journal of International Law (TEJoIL), 404.

${ }^{18}$ See: section 3.

${ }^{19}$ P. CHYNOWETH, 'Legal Research' in A. KNIGHT and L. RuDDOCK (eds.) Advanced Research in the Built Environment, Wiley-Blackwell, Oxford 2008, p. 29.

${ }^{20}$ R. AHDIEH, 'Between Dialogue and Decree. International Review of National Courts', (2004) 79 New York University Law Review, 2035.

${ }^{21}$ See: section 3.

${ }^{22}$ N. Bratza, 'Speech: Future of the ECtHR - Role of National Parliaments’, Strasbourg, 20.09.2012.

${ }^{23}$ Aslakhanova and Others v. Russia, No. 2944/06 et al., 18.12.2012, para. 210.
} 
47 States Parties to the ECHR. Third, the contribution only considers legal boundaries. Language and resource barriers, for example, can form practical boundaries to dialogue, but go beyond the scope of this research. Finally, the contribution only analyses one part of the dialogue that can take place between the domestic judges and the ECtHR and defines this dialogue as the possibility for a domestic court to 'reverse, modify or avoid' an ECtHR judgment or part thereof. ${ }^{24}$ This is only one part of the dialogue, since the domestic court's decision is a response to an ECtHR judgment, a response to which the ECtHR may reply in a subsequent judgment, which is possible if a comparable case is brought before it.

\section{THE INTERNATIONAL PERSPECTIVE}

This section explains which boundaries exist for the dialogue between the ECtHR and domestic judges from the international legal perspective. Section 2.1 describes the boundaries that can be derived from the Vienna Convention on the Law of Treaties (VCLT). The VCLT is considered, because the ECHR 'is an international treaty to be interpreted in accordance with the relevant norms and principles of public international law, and, in particular, in light of the [VCLT]' ${ }^{25}$ The boundaries based directly on the ECHR are discussed in two sections: the boundaries that apply in regard to dialogue with the states that area party to a case (section 2.2) and the boundaries that apply in regard to other ECHR member states that were not parties to the case (section 2.3).

\subsection{VCLT}

A provision in the VCLT on which the ECtHR has relied is Article 26 VCLT. This provision embodies the principle of pacta sunt servanda and stipulates that '[e]very treaty in force is binding upon the parties to it and must be performed in good faith' ${ }^{26}$ The States Parties to the ECHR, therefore, must perform the obligation to 'secure to everyone within their jurisdiction' the ECHR rights in good faith. ${ }^{27}$ Consequently, any dialogue with the ECtHR that influences a state's performance of the ECHR should take place in good faith. The ECtHR has also relied on Article 27 VCLT, to emphasize that a State 'may not invoke the provisions of its internal law as justification for its failure to perform a treaty'. ${ }^{28}$ Article 27 VCLT rule codifies the 'fundamental principle of international law that international law prevails over domestic law' ${ }^{29}$ This means that, in a dialogue, the States Parties cannot use their domestic laws as an argument to justify a failure to abide by the ECHR. The ECtHR does, however, not oblige the

\footnotetext{
${ }^{24}$ P.W. HogG and A.A. BushelL, 'The Charter Dialogue between Courts and Legislatures (Or Perhaps the Charter of Rights Isn’t Such a Bad Thing after All)', (1997) 35 Osgoode Hall Law Journal, p. 80.

${ }^{25}$ Naït-Liman v. Switzerland (GC), No. 51357/07, 15.03.2018, para. 174 (emphasis added).

${ }^{26}$ The ECtHR sometimes relies on this provision in its judgments see e.g.: Janowiec and Others v. Russia (GC), Nos. 55508/07 and 29520/09, 21.10.2013, para. 211.

${ }^{27}$ Article 1 ECHR.

${ }^{28}$ E.g. Janowiec and Others, supra note 23, para. 211.

${ }^{29}$ Applicability of the Obligation to Arbitrate under Section 21 of the United Nations Headquarters Agreement of 26 June 1947 (Advisory Opinion), ICJ Reports 1988, p. 12, para. 57; See also: Article 3 Draft articles on Responsibility of States for Internationally Wrongful Acts ('DARSIWA').
} 
States Parties to incorporate the Convention into domestic law; they must secure the Convention rights 'in some form or another' ${ }^{30}$

\subsection{ECHR: THE RESPONDENT STATE}

This section zooms in on the boundaries to dialogue that can be derived from the ECHR and that apply to the respondent State. The bottom line is that this State must abide by the operative provisions of the final Strasbourg judgment that establishes a breach of the ECHR. ${ }^{31} \mathrm{~A}$ failure to perform the 'unconditional' ${ }^{32}$ obligation to execute a judgment can engage a State's international responsibility. ${ }^{33}$ Therefore, no dialogue, however eloquent, can justify a failure to execute a judgment.

Executing a judgment means that the respondent State ends the breach, makes reparation for the consequences of the breach ${ }^{34}$ and guarantees non-repetition ${ }^{35} \cdot{ }^{36}$ These are obligations of result, meaning that the ECtHR does not prescribe how the obligation should be fulfilled. ${ }^{37}$ The respondent State is, therefore, in principle free to choose the means by which it will execute a judgment, ${ }^{38}$ provided the means are 'compatible with the conclusions set out in the Court's judgment'. ${ }^{39}$ Consequently, the respondent State can engage in a dialogue about which execution measures it will take. This dialogue normally takes place with the Committee of Ministers (CoM) and its Execution Department. ${ }^{40}$ The CoM assesses 'in light of [relevant] principles of international law and the information provided by the respondent State, whether the latter has complied in good faith' with the obligation to execute a judgment. $^{41}$

The ECtHR occasionally circumscribes the respondent State's freedom as to the choice of means and, thereby, the extent to which the State can engage in a dialogue with the CoM about the required execution measures. Most commonly, the ECtHR obliges the respondent State to pay a sum of money by way of just satisfaction to the applicant. ${ }^{42}$ This obligation is unconditional. ${ }^{43}$ Much more

\footnotetext{
${ }^{30}$ James and Others $v$. UK, No. 8793/79, 21.02.1986, para. 84.

${ }^{31}$ Article 46(1) ECHR.

${ }^{32}$ Ministers’ Deputies, 'Decision: Yukos v. Russia', CM/Del/Dec(2017)1280/H46-26, 10.03.2017, para. 3.

${ }^{33}$ VgT v. Switzerland (no. 2) (GC), No. 32772/02, 30.06.2009, para. 85.

${ }^{34}$ Papamichalopoulos and Others v. Greece (just satisfaction), No. 14556/89, 31.10.1995, para. 34.

${ }^{35}$ The ECtHR does not often mention the third obligation, but this obligation can be derived from, e.g., its statement that execution measures 'must also be taken in respect of other persons in the applicant's position, notably by solving the problems that have led to the Court's findings', see: Savriddin Dzhurayev v. Russia, No. 71386/10, 25.04.2013, para. 247.

${ }^{36}$ Case Concerning the Factory at Chorzów (Germany v. Poland) (Merits), PCIJ Reports Series A No. 17, p. 47 (which is a 'precious source of inspiration' for the ECtHR, see: Papamichalopoulos and Others, supra note 30, para. 36); Articles 28, 30-31 DARSIWA; Rules of the CoM for the supervision of the execution of judgments and of the terms of friendly settlements, Rule 6(2).

${ }^{37}$ Tagayeva and Others v. Russia, No. 26562/07, 13.04.2017, para. 638.

${ }^{38}$ Idem.

${ }^{39}$ Idem.

${ }^{40}$ Article 46(2) ECHR; GLAS, supra note 3, pp. 376-378.

${ }^{41}$ Savriddin Dzhurayev, supra note 35, para. 249.

${ }^{42}$ Article 41 ECHR.

43 J. POLAKIEWICZ, 'Speech: Between 'Res Judicata' and 'Orientierungswirkung - ECHR Judgments Before National Courts', Brno, 1921.06.2017.
} 
exceptionally, the ECtHR describes which other execution measures the respondent State must take. ${ }^{44}$ The degree of specificity of the descriptions varies: the descriptions of individual measures are usually relatively precise, ${ }^{45}$ whereas, for general measures, the ECtHR 'may propose various options and leave the choice of measure and its implementation to the discretion of the State concerned' ${ }^{46}$ Strictly legally speaking, the descriptions also vary in the sense that they can be an 'indication' that does not appear in the operative provisions or an 'order' that the ECtHR repeats in the operative provisions. ${ }^{47}$ In the latter case, states are not permitted to engage in a dialogue about the described execution measure. ${ }^{48}$

The respondent State does not have the right to appeal a judgment and to engage in a dialogue with the ECtHR in this manner. The parties to a case, however, can ask a Panel of five Grand Chamber judges to consider referring a Chamber case to the Grand Chamber. ${ }^{49}$ The Panel will do so only if the case raises a serious question affecting the interpretation or application of the ECHR or a serious issue of general importance. ${ }^{50}$ If the Panel accepts the request, it is possible to engage in a dialogue about the Chamber judgment.

\subsection{ECHR: THE OTHER STATES PARTIES}

The boundaries of dialogue applying to the respondent State, as described the previous section, do not apply to the States that are not a party to a case. Still, one can wonder whether these other States should 'take into account' the ECtHR's interpretation of the ECHR in a judgment to which they were not a party, ${ }^{51}$ because a judgment has res interpretata or interpretive authority. ${ }^{52}$ Although the ECHR does not regulate such authority 'precisely', ${ }^{53}$ the interpretive authority may be derived from the ECHR, the ECtHR's judgments and the ECtHR's comments on Protocol 16 ECHR, as is explained below. Additionally, this section specifies what the phrase 'take into account' can mean from the ECHR's perspective.

\subsubsection{The interpretive authority of the ECtHR judgments}

\footnotetext{
${ }^{44}$ GLAS, supra note 3, pp. 383-386.

${ }^{45}$ Idem, p. 389.

${ }^{46}$ Oleksandr Volkov v. Ukraine, No. 21722/11, 09.01.2013, para. 195.

${ }^{47}$ GLAS, supra note 3, pp., 391-392.

${ }^{48}$ Idem, p. 392.

${ }^{49}$ Article 43(1) ECHR.

${ }^{50}$ Article 43(2) ECHR; In practice, the panel refers only few cases for reconsideration to the Grand Chamber: in 2017, about six percent, see: ECTHR 2017, supra note 2, p. 156.

${ }^{51}$ Interlaken Declaration (2010), para. B(4)(c); O.M. ARNARDÓTTIR, 'Res Interpretata, Erga Omnes Effect and the Role of the Margin of Appreciation in Giving Domestic Effect to the Judgments of the European Court of Human Rights' (2017) 28 TEJoIL, 826.

${ }^{5}$ ARNARDÓTTIR, supra note 51, 825-826; See about this term: S. BESSON, 'The Erga Omnes Effect of Judgments of the European Court of Human Rights - What's in a Name?', in S. BESSON (ed.), The European Court of Human Rights after Protocol 14, Schulthess, Geneva 2011.

${ }^{53}$ A. BoDNAR, 'Res Interpretata: Legal Effects of the European Court of Human Rights' Judgments for other States Than Those which Were Party to the Proceedings', in Y. HAECK and E. BREMS, Human Rights and Civil Liberties in the 21 ${ }^{\text {st }}$ Century, Springer, Dordrecht 2014 , p. 224.
} 
Articles 1, 19 and 32 ECHR point to the interpretive authority of the ECtHR judgments. ${ }^{54}$ Article 19 establishes the ECtHR so it can ensure the observance of the engagements undertaken by the States, including the engagement to secure the ECHR rights by virtue of Article 1 ECHR. The establishment of a mechanism for reviewing compliance is, according to the ECtHR, 'one of the most significant features of the Convention system'. ${ }^{55}$ Article 32 ECHR stipulates that the ECtHR's jurisdiction extends to 'all matters concerning the interpretation and application of the Convention' that are referred to it in conformity with the ECHR. Since it is the ECtHR's task to interpret the ECHR - as the court of last instance ${ }^{56}$ and to ensure the engagements of the States Parties to secure the ECHR rights, the States should take into consideration the ECtHR's interpretation of the ECHR in judgments against other States Parties. Considering the content of Article 19 and 32 ECHR, a failure to do so arguably amounts to a violation of Article 1 ECHR and Article 26 VCLT. ${ }^{57}$

The ECtHR has acknowledged that its judgments 'establish precedents albeit to a greater or lesser extent' ${ }^{58}$ Furthermore, its judgments serve 'to elucidate, safeguard and develop the rules instituted by the Convention, thereby contributing to the observance by the States of the engagements undertaken by them' ${ }^{59}$ These quotes already indicate that the ECtHR attaches interpretive authority to its judgments. ${ }^{60}$ The structure of the judgments confirms this: they usually first outline the 'general principles' applicable to the relevant provision and then apply the principles to the case at hand. ${ }^{61}$ The ECtHR's acceptance of the interpretive authority can also be seen in its autonomous interpretation of certain terms in the ECHR, ${ }^{62}$ since an autonomous interpretation is 'transversally applicable to all the states' ${ }^{63}$ Moreover, the ECtHR draws consequences from the interpretive authority of its judgments: it expects that the domestic authorities act in accordance with the autonomous ECHR terms ${ }^{64}$ and that they apply the ECHR 'in the manner that most closely corresponds ... to the Convention as interpreted in the Court's case-law'. ${ }^{65}$ Comparably, the ECtHR can verify whether a State has 'sufficiently taken into

\footnotetext{
${ }^{54}$ A. DRZEMCZEWSKI, 'Quelques réflexions sur l'autorité de la chose interprétée par la Cour de Strasbourg', (2011) 58 Revista da Faculdade de Direito da UFMG, 87; BODNAR, supra note 53, pp. 224, 226-227; ARnARDÓTTIR, supra note 51, 824-825; PACE, 'The Future of the European Court of Human Rights and the Brighton Declaration', AS/Jur (2012) 42, 03.12.2012, para. 18; Cf. D.T. BJÖRGVINSSON, 'The Effect of the Judgments of the ECtHR before the National Courts - A Nordic Approach?', (2016) 85 Nordic Journal of International Law, 305.

${ }^{55} \mathrm{VgT}$, supra note 33, para. 84.

${ }^{56}$ Article 35(1) ECHR.

${ }^{57}$ BODNAR, supra note 53, 227; ARNARDÓTTIR, supra note 51, 825.

${ }^{58}$ Pretty v. UK, No. 2346/02, 29.04.2002, para. 75.

${ }^{59}$ Rantsev v. Cyprus and Turkey, No. 25965/04, 07.01.2010, para. 197; See also: Ireland v. UK, No. 5310/71, 18.01.1978, para. 154.

${ }^{60}$ M. O’BOYLE, 'Speech: The Convention as a Subsidiarity Source of Law', Skopje, 01-02.10.2010; DRZEMCZEWSKI, supra note 50, 90; BODNAR, supra note 53, p. 227; Venice Commission, 'Report on the Implementation of International Human Rights Treaties in Domestic Law and the Role of Courts', No. 690/2012, CDL-AD(2014)036, 08.12.2014, para. 52; VENICE COMMISSION, supra note 11, para. 96.

${ }^{6}$ J.H. GERARDS, 'The European Court of Human rights and the National Courts - Giving Shape to the Notion of 'Shared Responsibility' in J.W.A. FLEUREN and J.H. GERARDS (eds.), Implementatie van het EVRM en de uitspraken van het EHRM in de nationale rechtspraak. Een rechtsvergelijkend onderzoek, Radboud Universiteit, Nijmegen 2013, p. 78; E.g. Merabishvili v. Georgia (GC), No. 72508/13, 28.11.2017, paras. 181-208.

${ }^{62}$ E.g. Pellegrin v. France, No. 28541/95, 08.12.1999, para. 63.

${ }^{63}$ GERARDS, supra note 57, p. 78.

${ }^{64}$ Idem.

${ }^{65}$ Pla and Puncernau v. Andorra, No. 69498/01, 13.07.2004, para. 62 (emphasis added); See also: Kolevi v. Bulgaria, No. 1108/02, 05.12.2009, para. 214; Nunez v. Norway, No. 55597/09, 28.06.2011, para. 36; BESSON, supra note 52, p. 141.
} 
account the principles flowing from its judgments on similar issues, even when they concern other States'. ${ }^{66}$

In its reflection paper on the proposal for Protocol 16 ECHR, the ECtHR noted that, '[d]espite the fact that the advisory opinions would not have the binding character of a judgment ..., they would ... have "undeniable legal effects"'. ${ }^{67}$ The ECtHR added that it would consider the advisory opinions as 'valid case-law which it would follow when ruling on potential subsequent individual applications'. ${ }^{68}$ As in an advisory opinion, the ECtHR can decide on questions of principle in a judgment. ${ }^{69}$ When the ECtHR does so, a judgment is no different from an advisory opinion and therefore also has 'undeniable legal effects ${ }^{70}$ and will be relied upon by the ECtHR as 'valid case-law'. ${ }^{71}$ Therefore, the States Parties must consider such judgments.

The above leads to the conclusion that the Strasbourg judgments have interpretive authority. ${ }^{72}$ Indeed, the ECtHR's judges have acknowledged this authority ${ }^{73}$ and the States Parties have too. ${ }^{74}$ The States Parties must, therefore, in the words of the ECtHR, take the Strasbourg judgments with such authority 'sufficiently ... into account'.$^{75}$ Although it is clear that the ECtHR's judgments cannot be ignored, 'taking into account' is hardly a clear requirement and, therefore, does not help to delineate clearly the extent to which the States Parties can enter into a dialogue with the ECtHR. The next section aims to clarify this matter.

\subsubsection{The obligation to take into account}

The dictionary definition of to 'take into account' is 'to consider or remember something when judging a situation'. ${ }^{76}$ 'To consider' can be defined as 'to give attention to a particular subject or fact when judging something else' ${ }^{77}$ Indeed, the domestic judges must consider the ECtHR judgments when adjudicating something else: the case before them with its specific factual and legal context. ${ }^{78}$

\footnotetext{
${ }^{66}$ Opuz v Turkey, No. 33401/02, 09.06.2009, para. 163; See also: BESSON, supra note 52, p. 138; Ylldırım v. Turkey, No. 3111/10, 18.12.2012, para. 66; Fabris v. France (GC), No. 16574/08, 07.02.2013, para. 75.

67 ECTHR, 'Reflection Paper on the Proposal to Extend the Court's Advisory Jurisdiction', <www.echr.coe.int/Documents/2013_Courts_advisory_jurisdiction_ENG.pdf> accessed 20.03.2018, para. 44. The ECtHR cites the InterAmerican Court of Human Rights see: footnote 46 of the Reflection Paper.

${ }^{68}$ Idem; See also: Explanatory Memorandum to Protocol 16 ECHR, para. 27.

${ }^{69}$ This is in particular the task of the Grand Chamber, see: Articles 30 and 43(2) ECHR.

${ }^{70}$ See: supra note 67.

${ }^{71}$ See: supra note 68

72 See also: POLAKIEWICZ, supra note 43. It can also be regarded as 'sound judicial policy’, see: BJÖRGVINSSON, supra note 51, p. 305.

73 ECTHR, 'Memorandum of the President to the European Court of Human Rights to the States with a View to Preparing the Interlaken Conference,' 03.07.2009, <www.echr.coe.int/Documents/Speech_20090703_Costa_Interlaken_ENG.pdf> accessed 20.03.2018, p. 6; M. LAZAROVA TRAJKOVSKA, 'Speech: Ways and means to recognise the interpretative authority of judgments against other States', Skopje, 01-02.10.2010; Fabris, supra note 66, Concurring opinion of judge Pinto de Albuquerque; Al-Dulimi and Montana Management Inc. v. Switzerland, No. 5809/08, 21.06.2016, Concurring opinion of judge Pinto de Albuquerque, joined by Judges Hajiyev, Pejchal and Dedov, para. 60 .

${ }^{74}$ Interlaken Declaration (2011), para. B(4)(c); Brighton Declaration (2012), paras. 7, 9(iv); Brussels Declaration (2015), para. B(I)d.

${ }^{75}$ Opuz, supra note 66, para. 163.

${ }^{76}$ Cambridge Dictionary (English), <https://dictionary.cambridge.org/> accessed 19.03.2018.

${ }^{77}$ Idem.

${ }^{78}$ ARNARDÓTTIR, supra note 51, 831; See also: BoDNAR, supra note 53, p. 238.
} 
Since the domestic judges unavoidably adjudicate something else than the ECtHR and because the ECtHR delivers judgments in individual cases, which establish principles to 'a greater or larger extent' ${ }^{79}$ the domestic judges cannot blindly follow Strasbourg. Therefore, the more the ECtHR's reasoning is intertwined with the facts of the individual case, the harder it becomes to simply copy its reasoning. The obligation to take into account, in short, cannot be an obligation to follow the ECtHR. Instead, the obligation requires that the domestic judges decide on the relevance of a Strasbourg judgment to the case before them and distinguish relevant differences. ${ }^{80}$ When making this decision, the judges cannot rely on domestic law to justify not taking into account an ECtHR judgment. ${ }^{81}$ These judges must also demonstrate good faith, ${ }^{82}$ which can be interpreted to mean, in the current context, that they give reasons for the course they have taken. In the absence of any reasoning, it will be hard for the ECtHR to respond and thus to engage in dialogue. ${ }^{83}$

Since the domestic judges should take into account the Strasbourg judgments because these judgments have interpretive authority, the question arises how it can be established to what extent a judgment has such authority. I propose that the judgments are neither authoritative nor lacking all authority, but authoritative to a greater or lesser extent. ${ }^{84}$ The authoritativeness of a judgment can be assessed based on different factors, as is discussed below. These factors offer viewpoints that do not necessarily point in the same direction; they are, therefore, not prerequisites that must all be fulfilled before a judgment should be taken into account. The factors are derived from features of the ECHR system and are based on a practical consideration.

One factor is the formation that has delivered the judgment. ${ }^{85}$ The Grand Chamber of seventeen judges is the ECtHR's largest and, therefore, most 'inclusive' formation whose 'reasoning has benefited from enhanced deliberation'. ${ }^{86}$ This formation decides cases raising 'a serious question affecting the interpretation or application of the Convention ... or a serious issue of general importance'. ${ }^{87}$ These features make a Grand Chamber judgment, in principle, more authoritative than a judgment of a Chamber of seven judges or a judgment of a Committee of three judges. ${ }^{88}$ Additionally, one could check the size of the majority that has adopted the judgment and the content of any concurring opinions. ${ }^{89}$ When a nine-to-eight majority adopts a Grand Chamber judgment and when some judges explain in

\footnotetext{
${ }^{79}$ Pretty, supra note 58, para. 75.

${ }^{80}$ As the ECtHR does, see e.g.: O'Halloran and Francis v. UK, Nos. 15809/02 and 25624/02, 29.06.2007, para. 43.

${ }^{81}$ See: sections 2.1 and 2.2 .

${ }^{82}$ Idem.

${ }^{83}$ See also: GLAS, supra note 3, pp. 162-165.

${ }^{84}$ See also: E. LAMBERT, Les effets des arrêts de la Cour européenne des droits de l'homme, Bruylant, Brussels 1999, pp. 304-305.

${ }^{85}$ BESSON, supra note 52, p. 169.

${ }^{86}$ Idem.

${ }^{87}$ Article 43 ECHR; See also: Article 30 ECHR.

${ }^{88}$ See also: A. CALIGIURI and N. NAPOLETANO, 'The Application of the ECHR in Domestic Proceedings' (2010) 20 Italian Yearbook of International Law, 158; BoDNAR, supra note 53, p. 237; CDDH, 'Report on the longer-term future of the system of the European Convention on Human Rights’, CM(2015)176-add1final, 03.02.2016, para. 131; ARNARDÓTTIR, supra note 51, 841.

${ }^{89}$ See also: BODNAR, supra note 53, p. 241.
} 
their concurring opinions that they have reached the same conclusion as the majority, but for different reasons than the majority, that judgment inevitably is less authoritative than a Grand Chamber with a larger majority and without concurring opinions.

In addition to the formation, the domestic judges can also check 'the degree of entrenchment of a precedent'.$^{90}$ If the ECtHR has applied a certain interpretation repeatedly, without overruling it, the authoritativeness of that interpretation increases. ${ }^{91}$ However, when a precedent, even when it is well established, is rather old, ${ }^{92}$ this may undermine its authoritativeness, especially when the consensus in the States Parties about a certain matter has evolved. ${ }^{93}$ A changed consensus is relevant, because the ECHR is a 'living instrument' that 'must be interpreted in the light of present-day conditions' ${ }^{94}$

From a practical perspective, the clarity of a judgment is relevant. The clearer an ECtHR judgment is, the easier it becomes to take it into account. ${ }^{95} \mathrm{~A}$ clear statement is, for example, that 'a general, automatic and indiscriminate restriction ${ }^{96}$ on prisoner voting violates Article 3 Protocol 1 ECHR. ${ }^{97}$

The result of taking into account the same branch of case-law, can lead to different results in different States. ${ }^{98}$ Different results are not only unavoidable since the factual and legal circumstances differ in each case, but also because a matter may fall within the margin of appreciation of the domestic authorities. A margin of appreciation applies in particular if ECHR rights are restricted, i.e. are 'balanced' against another ECHR right or against a public interest, such as public safety. ${ }^{99}$ Furthermore, different results are possible, because the States may go beyond the protection that the ECHR, as interpreted by the ECtHR, offers. ${ }^{100}$

\subsection{SUB-CONCLUSION}

Irrespective of whether a State is a respondent State, it must engage in a dialogue in good faith and cannot rely on domestic laws to justify a failure to follow the ECtHR. The boundaries to dialogue that apply to the respondent State are rather strict. Its room for dialogue is limited by the unconditional

\footnotetext{
${ }^{90}$ BEsson, supra note 52, pp. 161, 169.

${ }^{91}$ Idem, p. 169; See also: LAMBERT, supra note 84, p. 305; CALIGIURI and NAPOLETANO, supra note 88, 158; CDDH, supra note 88, para. 131; ARNARDÓTTIR, supra note 51, 841.

${ }^{92}$ See also: CALIGIURI and NAPOLETANO, supra note 88, 158.

${ }^{93}$ See also: BESSON, supra note 52, p. 167.

${ }^{94}$ Tyrer v UK, No. 5856/72, 25.04.1978, para. 31.

${ }^{95}$ LAMBERT, supra note 84, p. 305; Brighton Declaration (2012), para. 23; BESSON, supra note 52, p. 163; BoDNAR, supra note 53, pp. 239-

240; ARNARDÓTTIR, supra note 51, 841.

${ }^{96}$ Hirst v. UK (no. 2) (GC), No. 74025/01, 06.10.2005, para. 82.

${ }^{97}$ ARNARDÓTTIR, supra note 51, 841.

98 POLAKIEWICZ, supra note 43.

${ }^{99}$ S. GREER, The Margin of Appreciation: Interpretation and Direction under the European Convention on Human Rights, Council of Europe Publishing, Strasbourg 2000, pp. 24-26.

${ }^{100}$ Article 53 ECHR; Besson, supra note 52, p. 167; Hutchinson v UK, No. 57592/08, 17.01.2017, Dissenting Opinion of Judge Pinto de Albuquerque, para. 41.
} 
requirement to execute a judgment by ending a breach, providing reparation and guaranteeing nonrepetition. The respondent State, therefore, cannot engage in dialogue about the result it must achieve, ${ }^{101}$ but it can engage in dialogue about the means that it chooses. When the ECtHR spells out part of the result to be achieved, tighter boundaries apply. The respondent State does not have the right to engage in dialogue by way of appealing a judgment.

The other States Parties have more room to engage in dialogue than the respondent state, although they must take certain judgments into account. Therefore, these States cannot simply ignore what Strasbourg has said. They are, however, not obliged to blindly follow Strasbourg or to follow the same course of action as another State. The extent to which a judgment must be followed depends on its authoritativeness, which can be determined with the help of these factors: the size of the majority, the content of concurring opinions and the entrenchment and clarity of the judgment. If the State does not follow Strasbourg, the requirement of good faith necessitates motivating that decision.

\section{THE DOMESTIC PERSPECTIVES}

The previous section concerned the international legal boundaries that apply to domestic courts' dialogue with the ECtHR. This section will discuss these boundaries from the perspective of eleven domestic legal systems (sections 3.1-3.11) and ends with a section (3.12) that includes some general observations about the domestic approaches and that compares these approaches.

\subsection{AUSTRIA}

The Austrian judges seek to interpret the Convention, which is part of the Constitution, in accordance with the ECtHR's case law; ${ }^{102}$ that body of case law is 'the relevant point of reference of [the Constitutional Court's] own interpretation' ${ }^{103}$ The Constitutional Court has, moreover, emphasized that it “"abides” by the ECtHR's case law, even where this requires it to “depart” from its own, previous case law' ${ }^{104}$ Nevertheless, the Constitutional Court decided in the Miltner judgment ${ }^{105}$ that it could not follow the ECtHR's increasingly broad interpretation of 'civil rights' under Article 6 ECHR. ${ }^{106}$ It refused to follow, because following would require amending the Constitution, something that only

\footnotetext{
${ }^{101}$ Provided the result to be achieved is clear. If the result to be achieved is not very clear, this opens up some room for domestic judges to make different choices.

${ }^{102}$ K. PABEL, 'Speech: The implementation of judgments of the European Court of Human Rights in Austria', Saint-Petersburg, 22-23.10.2015; A. GAMPER, 'Austria: Endorsing the Convention System, Endorsing the Constitution’ in P. PoPELIER, S. LAMBRECHT and K. LEMMENS (eds.) Criticism of the European Court of Human Rights, Intersentia, Cambridge 2016, p. 95.

${ }^{103}$ GAMPER, supra note 105, p. 94-95.

${ }^{104}$ Idem, referring to VsSlg 15.129/1998, 19.166/2010.

${ }^{105}$ VfSlg 11.500/1987.

${ }^{106}$ GAMPER, supra note 105, p. 79.
} 
parliament can do, although the Constitutional Court can call on parliament to do so. ${ }^{107}$ The Constitutional Court additionally noted that the ECHR 'had developed in a way that led to new obligations for the State Parties that they had never been willing to accept', ${ }^{108}$ thus criticising the ECtHR's dynamic interpretation of the ECHR. ${ }^{109}$ Only one year after the Miltner judgment, the Constitutional Court furthermore remarked that it could not interpret the ECHR in line with the Strasbourg case law at all times, because 'it was necessary to interpret the ECHR in a systemic context with all other parts of the' Constitution. ${ }^{110}$ The Constitutional Court thus points out that it must also consider other Constitutional provisions than the ECHR (as interpreted by the ECtHR). The approach of the Constitutional Court has led it to not only interpret Article 6 ECHR differently from the ECtHR; it also adopted a less broad definition of the scope of Article 1 of Protocol 1 ECHR than the ECtHR ${ }^{111}$ and it approaches the question of the 'same offence' under Article 4 of Protocol 7 ECHR slightly differently from the ECtHR. ${ }^{112}$ Still, the number of cases in which the Constitutional Court does not follow the ECtHR completely, remains 'relatively small'. ${ }^{113}$

\subsection{BELGIUM}

From a formal, legal point of view, 'the ECtHR's judgments are not part of the national legal system and they only have declaratory force'. ${ }^{114}$ These judgments are, therefore, only binding 'regarding the concrete disputes resolved'. ${ }^{115}$ Nevertheless, the Constitutional Court is described as 'Strasbourgfriendly, ${ }^{116}$ and takes into account the Strasbourg judgments, including those against other states, 'as if they were binding'. ${ }^{117}$ Yet, the Constitutional Court may be reluctant to 'fully follow' the ECtHR at all times, ${ }^{118}$ although its 'deviances ... remain rare'. ${ }^{119}$ The main course of contention seems to be that the Constitutional Court is more willing than the European judges to 'accept the legislature's assumptions and to appeal to the general interest to justify interferences with fundamental rights', whereas the ECtHR

\footnotetext{
${ }^{107}$ M. STELZER, The Constitution of the Republic of Austria: A Contextual Analysis, Hart Publishing, Oxford 2011, p. 183; PABEL, supra note 105.

${ }^{108}$ D. ThurnherR, ‘Austria and Switzerland’ in H. KELLER and A. STONE SwEET, A Europe of Rights: The Impact of the ECHR on National Legal Systems, OUP, Oxford 2008, p. 361.

${ }^{109}$ GAMPER, supra note 105, p. 79.

${ }^{110}$ Idem, p. 95, referring to VfSlg 11.937/1988.

111 THURNHERR, supra note 111, pp. 362-363; The author refers to VfSlg 4879/1964, 6648/1972, 6733/1972, 11198/1986; More recently, the Constitutional Court has shown also 'an inclination to follow the ECtHR's case law' at this point, see GAMPER, supra note 105, p. 96, referring to VfSlg 18.069/2007, 19.341/2011.

112 See the judgment of 02.07.2009, B 559/08, summarised in English by CODICES, <www.codices.coe.int/NXT/gateway.dll/Codices/Precis/ENG/EUR/AUT/AUT-2009-3-002?f=templates\$fn=documentframeset.htm $\$ q=\$ u q=\$ x=\$ u p=1>$ accessed on 10.05.2018; See also GAMPER, supra note 105, p. 97.

${ }^{113}$ GAMPER, supra note 105, p. 95.

${ }^{114}$ P. Popelier and K. Lemmens, The Constitution of Belgium. A Contextual Analysis, Hart Publishing, Oxford 2015 , p. 229.

${ }^{115}$ Oxford Pro Bono Publico, 'Reconciling domestic superior courts with the ECHR and the ECtHR: A Comparative Perspective (Submission to the Commission on a Bill of Rights)', 24.11.2011 < https://issuu.com/opbp/docs/2011_-_echr_and_domestic_courts > accessed 20.03.2018, p. 20.

${ }^{116}$ P. POPELIER, 'Belgium: Faithful, Obedient, and Just a Little Irritated' in P. POPELIER, S. LAMBRECHT and K. LEMMENS (eds.) Criticism of the European Court of Human Rights, Intersentia, Cambridge 2016, p. 119.

${ }^{117}$ G. SCHAIKO, P. LEMMENS and K. LEMMENS, 'Belgium', in J.W.A. FLEUREN and J.H. GERARDS (eds.), Implementatie van het EVRM en de uitspraken van het EHRM in de nationale rechtspraak. Een rechtsvergelijkend onderzoek, Radboud Universiteit, Nijmegen 2013, p. 159: See also: POPELIER and LEMMENS, supra note 117, p. 229.

${ }^{118}$ SCHAIKO, LEMMENS and LEMMENS, supra note 120, p. 154

${ }^{119}$ POPELIER, supra note 119, p. 125.
} 
seems to attach more importance to 'evidence-based substantiation' in this regard. ${ }^{120}$ According to some authors, the Constitutional Court will 'provide extensive reasoning' for its deviances; ${ }^{121}$ according to another author, its deviances are 'implicit'. ${ }^{122}$ The Council of State, for its part, follows Strasbourg judgments, regardless of whether Belgium was a party to a case, seemingly without limiting 'their effects in the Belgian legal order'. ${ }^{123}$ The Court of Cassation is also regarded as 'Strasbourg-friendly' and accepts the interpretative authority of the ECtHR's judgments. ${ }^{124}$ Nevertheless, this court, due to its lack of a tradition of 'source referencing', seems to ignore Strasbourg case law or refers to it implicitly or in abstracto. ${ }^{125}$ Furthermore, this court may interpret Strasbourg judgments against other states restrictively and seems to be more reluctant than the Constitutional Court to follow. ${ }^{126}$ The Court of Cassation interpreted, for example, the Salduz v. Turkey ${ }^{127}$ judgment restrictively in the period before the legislature took action with respect to the judgment. ${ }^{128}$ This was, however, not a sign of hostility, as the Court of Cassation aimed at compliance 'in good faith', 'while at the same time, for pragmatic reasons, it did not want to complicate criminal proceedings to such an extent that, until further action by the legislature, investigators would be faced with practical difficulties of considerable importance'. ${ }^{129}$ Also more in general, if a Strasbourg judgment goes against its own practice, the Court of Cassation does not 'openly contest' the judgment, but instead 'tries to find a pragmatic solution'. ${ }^{130}$

\subsection{GERMANY}

In Görgülü, the Federal Constitutional Court explained 'the relevance of the judgments of the [ECtHR] in German law’. ${ }^{131}$ These judgments, including judgments rendered against Germany, are not binding, ${ }^{132}$ but the domestic judges must 'duly consider' ${ }^{133}$ the ECHR as interpreted by the ECtHR. ${ }^{134}$ Failing to do so, 'may pave the way for an individual constitutional complaint alleging that the corresponding constitutional right ... and the Rechtsstaat principle have been violated'. ${ }^{135}$ The domestic judges may disagree with the ECtHR, considering that the former may need to decide in 'multipolar' fundamental rights situations, ${ }^{136}$ for example in civil law, where 'conflicting fundamental rights' need to be

\footnotetext{
${ }^{120}$ Idem.

${ }^{121}$ SCHAIKO, LEMMENS and LEMMENS, supra note 120, p. 154, referring to this example: Const. Ct., No. $153 / 2007$.

${ }^{122}$ POPELIER, supra note 119, p. 125.

123 SCHAIKO, LEMMENS and LEMMENS, supra note 120, p. 159.

${ }^{124}$ POPELIER, supra note 119, p. 121, referring to Cass. C.08.0384N, 10.06.2009.

${ }^{125}$ Idem, p. 122.

${ }^{126}$ SCHAIKO, LEMMENS and LEMMENS, supra note 120, p. 159; POPELIER, supra note 119, p. 125.

127 (GK), No. 36391/02, 27.11.2008.

${ }^{128}$ SCHAIKO, LEMMENS and LEMMENS, supra note 120, p. 159, referring to Cass. No. P.12.0106.N, 24.01.2012.

${ }^{129}$ Idem, referring to idem.

${ }^{130}$ POPELIER, supra note 119, p. 125.

${ }^{131}$ K. PABEL, 'Germany: The Long Way of Integrating the Strasbourg Perspective into the Protection of Fundamental Rights' in P. POPELIER,

S. LAMBRECHT and K. LEMMENS (eds.) Criticism of the European Court of Human Rights, Intersentia, Cambridge 2016 , p. 165.

${ }^{132}$ E. KLEIN, 'Germany' in J.W.A. FLEUREN and J.H. GERARDS (eds.), Implementatie van het EVRM en de uitspraken van het EHRM in de nationale rechtspraak. Een rechtsvergelijkend onderzoek, Radboud Universiteit, Nijmegen 2013, pp. 211-212; BVerfG, 2 BvR 1481/04 of 14.10.2004 ('Görgülü’), para. 48.

133 Görgülü, supra note 135, para. 62.

${ }^{134}$ Idem, para. 48.

${ }^{135}$ KLEIN, supra note 135, 212.

${ }^{136}$ Görgülü, supra note 135, para. 50.
} 
balanced. ${ }^{137}$ The ECtHR, more narrowly, decides on the dispute between an individual and the State ${ }^{138}$ and, therefore, may not consider all 'the legal positions and interests involved'. ${ }^{139}$ Furthermore, the 'actual or legal circumstances ${ }^{140}$ before the domestic judge may be different from the circumstances as presented before the ECtHR, which also justifies a departure from a Strasbourg judgment. ${ }^{141}$ The Constitutional Court has also formulated the rule that reliance on the ECtHR's case-law may not decrease the protection that an individual enjoys under the Basic Law ${ }^{142}$ or violate 'prior-ranking law, in particular constitutional law'. ${ }^{143}$ The domestic judges must justify a departure from the ECtHR 'understandably'. ${ }^{144}$

In Preventive Detention II, ${ }^{145}$ the Constitutional Court explained more specifically that the ECHR obligations should be 'translated' 146 'to the specificities of the German legal system'. ${ }^{147}$ Thus, the domestic judges have 'some leeway' when they cannot follow Strasbourg precisely. ${ }^{148}$ Nevertheless, they tried to avoid going against the ECtHR, ${ }^{149}$ aiming for dialogue rather than hostility, ${ }^{150}$ and they regarded the ECHR and the ECtHR's case law as interpretative 'aids'. ${ }^{151}$ Therefore, when German and ECHR law are incompatible, the domestic judges will try to remove the compatibility. ${ }^{152}$ In the aforementioned judgment, the Constitutional Court was confronted with the incompatibility between its own previous judgment that declared certain domestic legal provisions constitutional and a European judgment. ${ }^{153}$ The Constitutional Court removed this incompatibility by qualifying the latter judgment as a 'legally relevant change', which meant it could set aside its own judgment. ${ }^{154}$

\subsection{ICELAND}

The Icelandic ECtHR Act stipulates in Article 2 that the ECtHR judgments, including those against Iceland, 'are not binding in Icelandic domestic law'. ${ }^{155}$ The explanatory report to this provision clarifies

\footnotetext{
${ }^{137}$ Idem, para. 58.

${ }^{138}$ Idem.

${ }^{139}$ Idem, para. 59.

${ }^{140}$ Idem, para. 50.

${ }^{141}$ Idem, para. 50.

${ }^{142}$ Idem, para. 32.

${ }^{143}$ Idem, para. 62.

${ }^{144}$ Idem, para. 48.

145 BVerfGE 128, 04.05.2011, 326; Welcomed by the ECtHR in Schmitz v. Germany, No. 30493/04, 09.06.2011, para. 41.

${ }^{146}$ B. BJORGE, Domestic Application of the ECHR: Courts as Faithful Trustees, OUP, Oxford 2015, p. 77.

147 A. NußBerger, 'The European Court of Human Rights and the German Federal Constitutional Court', <www.cak.cz/assets/proadvokaty/mezinarodni-vztahy/the-echr-and-the-german-constitutional-court_angelika-nussberger.pdf> accessed 20.05.2018, 10.

${ }^{148}$ BJORGE, supra note 149, p. 77.

${ }^{149}$ Idem, p. 91.

${ }^{150}$ PABEL, supra note 134, p. 170.

${ }^{151}$ Idem, p. 167.

152 BJoRge, supra note 149, p. 92; See e.g. also Von Hannover No. 2 v. Germany, No. 40660/08 and 60641/08, para. 114-123, in which the ECtHR approves the new approach of the German Federal Constitutional Court, which it adopted in No. 1 BvR 1606/07, 26.02.2008; See for a description of these cases: PABEL, supra note 134, pp. 169-170.

153 PABEL, supra note 134, p. 168.

${ }^{154}$ Idem.

${ }^{155}$ D.T. BJÖRGVINSSON, 'The Effect of the Judgments of the ECtHR before the National Courts - A Nordic Approach?' in A. KJELDGAARDPedersen (ed.), Nordic Approaches to International Law, Nijhoff, Leiden 2018, p. 105.
} 
that domestic judges must interpret the ECHR 'independently' ${ }^{156}$ and, therefore, 'regardless of' the Strasbourg case-law. ${ }^{157}$ The same report assumes nevertheless that the domestic judges will turn to the ECtHR's case-law for guidance when interpreting the ECHR. ${ }^{158}$ Comparably, the Icelandic Supreme Court has noted that the ECtHR's interpretation should be 'considered' and interprets domestic law whilst taking into consideration the ECHR and the ECtHR's case law. ${ }^{159}$ More generally, that court has 'sought to interpret Icelandic law in conformity with Iceland's international obligations'. ${ }^{160}$

\subsection{ITALY}

According to the Italian Constitutional Court in 2007, the domestic judges should take the ECtHR judgments into consideration when interpreting the ECHR, ${ }^{161}$ which amounted to an 'unconditional obligation ... to give to the Convention only the meaning given to it by the ECtHR' ${ }^{162}$ Moreover, in 2009, the Constitutional Court ruled that the ECtHR's interpretation of the ECHR had 'binding effect', ${ }^{163}$ considering that it is the ECtHR's task to interpret the ECHR under Article 32 ECHR. ${ }^{164}$ Consequently, domestic judges cannot interpret the ECHR differently from the ECtHR ${ }^{165}$ and they can only influence the ECHR's interpretation where the ECtHR has not yet ruled on a certain matter. ${ }^{166}$ The court added, however, that 'only the essence of the case of the ECtHR should be binding'. ${ }^{167}$ Thus, the Constitutional Court created some room for divergence from Strasbourg and could, thus, prevent a 'direct clash' when not following Strasbourg entirely. ${ }^{168}$ The Constitutional Court probably came up this technique, because the constraints that it had imposed upon itself gave it 'too little room for manoeuvre with regards to the ECtHR case law'. ${ }^{169}$ Subsequently, the Constitutional Court has invented other techniques that provide room for manoeuvre. ${ }^{170}$ One such technique is that of distinguishing between a relevant Strasbourg judgment and the case before it. ${ }^{171}$ Additionally, whilst noting that the Italian judges should not be 'passive recipients' of the ECtHR, the Constitutional Court explained that these judges

\footnotetext{
${ }^{156}$ Idem, p. 106 (emphasis in original).

${ }^{157}$ Idem, p. 107.

${ }^{158}$ G. GAUKSDOTTIR and T. INGADOTTIR, 'Compliance with the Views of the UN Human Rights Committee and the Judgments of the European Court Of Human Rights in Iceland’ in A. EIDE, J.TH. MöLleR and I. ZIEMELE, Making Peoples Heard: Essays on Human Rights in Honour of Gudmundur Alfredsson, Nijhoff, Leiden 2011, p. 513.

${ }^{159}$ R. HELGADOTTIR, 'Nonproblematic judicial review: A case study', (2011) 9 International Journal of Constitutional Law, 538; The case the author refer to is from 2005.

${ }^{160}$ GAUKSDOTTIR and INGADOTTIR, supra note 161, p. 514; The authors give the following judgment as an example: H 2000,4480 (section IV, para. 2).

${ }^{161}$ G. MARTINICO, 'National courts and judicial disobedience to the ECHR: a comparative overview', in O.M. ARNARDÓTTIR and A. BUYSE (eds.), Shifting Centres of Gravity in Human Rights Protection: Rethinking Relations Between the ECHR, EU, and National Legal Orders, Routledge, New York 2017, p. 69.

${ }^{162}$ O. POLLICINO, 'The European Court of Human Rights and the Italian Constitutional Court: No ‘Groovy Kind of Love’' in K. SIEGLER (ed.) The UK and of European Court of Human Rights - A Strained Relationship?, Hart Publishing, Oxford and Portland 2015 , p. 371.

${ }^{163}$ CALIGIURI and NAPOLETANO, supra note 87, 157, referring to judgment No. 317 of 2009.

${ }^{164}$ Idem; See also: BODNAR, supra note 53, p. 234.

165 CALIGIURI and NAPOLETANO, supra note 87, 157, referring to judgment No. 317 of 2009.

${ }^{166}$ Idem, 158.

${ }^{167}$ Pollicino, supra note 165, p. 372 (emphasis added).

${ }^{168}$ Idem, pp. 372-373.

${ }^{169}$ Idem, p. 371.

${ }^{170}$ G. MARTINICO, 'Italy: Between Constitutional Openness and Resistance’ in P. Popelier, S. LAMBrECHT and K. LEMMENS (eds.) Criticism of the European Court of Human Rights, Intersentia, Cambridge 2016, p. 193.

${ }^{171}$ Pollicino, supra note 165, p. 372-373.
} 
should take into account the conditions giving rise to the ECtHR's interpretations. ${ }^{172}$ More specifically, the judges should only follow pilot judgments, ${ }^{173}$ judgments concerning ‘a specific individual dispute remitted to the national court ${ }^{174}$ and well-established case-law. ${ }^{175} \mathrm{~A}$ judgment does not count as wellestablished when 'some' of these indicators apply: ${ }^{176}$ the judgment is innovative, the judgment conflicts with other judgments, 'robust' dissents have been written, the Grand Chamber has not endorsed the judgment or the domestic judges doubt if the ECtHR 'had correctly considered the peculiar characteristics of the domestic legal system at stake'. ${ }^{177}$ Yet another technique that creates room for manoeuvre, is to emphasize 'the differences existing in terms of contexts' ${ }^{178}$ between the Constitutional Court and the ECtHR: ${ }^{179}$ whilst the latter performs an 'isolated' evaluation, the former performs a 'systemic' evaluation 'of the values involved by the norm under analysis, and it is therefore obliged to [perform a] balancing exercise'. ${ }^{180}$

\subsection{LATIVA}

The Latvian Constitutional Court has ruled that the domestic judges are bound to the ECtHR's case-law, also in respect of judgments not issued against Latvia. Additionally, the Latvian judges must rely on the Strasbourg judgments when interpreting the Constitution; ${ }^{181}$ these judgments serve as 'means of interpretation'. ${ }^{182}$ Still, the Constitutional Court 'has elaborated its own understanding of the content and scope of' the Constitutional rights. ${ }^{183}$ A case in point is the reaction of the Constitutional Court to the judgment Andrejeva v. Lativa, ${ }^{184}$ in which the ECtHR found a violation of Article 14 ECHR in conjunction with Article 1 of Protocol No 1 ECHR, because the applicant was denied a retirement pension for the years employed in the USSR, because she did not have Latvian citizenship. ${ }^{185}$ In response, the Constitutional Court maintained 'Latvia's principled position that Latvia was not the successor to the obligations of the USSR, and that such rights that may have been acquired during the times of the USSR could not be binding upon Latvia in calculating pensions'. ${ }^{186}$ The Latvian judges

\footnotetext{
${ }^{172}$ MARTINICO, supra note 165, p. 77, referring to decision No. 49/2015.

${ }^{173}$ G. NESSI, 'Constitutionality of legislation imposing confiscation without conviction', Oxford Reports on International Law, 2016, para. H12.

${ }^{174}$ D. TEGA, ‘A National Narrative: The Constitution’s Axiological Prevalence on the ECHR-A Comment on the Italian Constitutional Court Judgment No. 49/2015’, International Journal of Constitutional Law Blog, 01.05.2015.

${ }^{175}$ NESSI, supra note 176, para. H6.

${ }^{176}$ Idem, para. H12.

${ }^{177}$ Idem, para. H11.

${ }^{178}$ MARTINICO, supra note 173, p. 191.

${ }^{179}$ Idem, p.187, referring to and citing judgment No. 230 of 2012.

${ }^{180}$ Idem, referring to and citing idem.

${ }^{181}$ I. JARUKAITIS, 'Report on Estonia, Latvia and Lithuania’, in G. MARTINICO and O. PoLLICINO (eds.), The National Judicial Treatment of the ECHR and EU Laws, Europa Law Publishing, Groningen, 2010, p. 178; M. MITS, 'Latvia' in I. MotOC and I. ZIEMELE, The Impact of the ECHR on Democratic Change in Central and Eastern Europe, CUP, Cambridge 2016, p. 216; A. CozzI et. al., Comparative Study on the Implementation of the ECHR at the National Level, Council of Europe, Belgrade 2015, p. 20.

${ }^{182}$ I. ZIEMELE, 'Speech: The Significance of the European Convention for the Protection of Human Rights and Fundamental Freedoms in the Case-Law of the Constitutional Court of the Republic of Latvia', 02.10.2017, Ljubljana, referring to the judgment of 13.05 .2005 in the case no. 2004-18-0106 and the judgment of 18.10.2007 in the case no. 2007-03-01.

${ }^{183}$ Idem.

184 (GK), No. 55707/00, 18.02.2009.

${ }^{185}$ ECtHR, 'Press release issued by the Registrar. GRAND CHAMBER JUDGMENT ANDREJEVA v. LATVIA', 18.02.2009.

${ }^{186}$ ZIEMELE, supra note 185.
} 
justified their refusal to follow Strasbourg ${ }^{187}$ by explaining that the ECtHR had 'assessed only particular facts rather than compliance of the contested norm with legal norms of a higher legal force' and by pointing out that the facts in the case before it were 'considerably' different from the facts in Andrejeva. ${ }^{188}$ Additionally, the Constitutional Court emphasised the wide margin of appreciation that states have in relation to socioeconomic policies. ${ }^{189}$

\subsection{THE NETHERLANDS}

With reference to the 'incorporation doctrine', the Dutch judges interpret the ECHR as the ECtHR has interpreted that document, regardless of whether a specific judgment was rendered against the Netherlands. ${ }^{190}$ Although this approach means that the judges follow the ECtHR 'loyally', they do not follow 'slavishly'. ${ }^{191}$ The Supreme Court interpreted the Salduz v. Turkey judgment, for example, in a 'narrow' manner, ${ }^{192}$ not so much because it was critical of the ECtHR, but due to 'the limitations of its role within the Dutch constitutional system'; ${ }^{193}$ it was 'beyond its judicial task to change the relevant legislation'. ${ }^{194}$ Reluctance to follow Strasbourg, may, however, also be 'more substantially driven'. ${ }^{195}$ In these circumstances, the domestic judges do not follow Strasbourg precisely or only minimally, without making this very explicit, ${ }^{196}$ because they disagree with a European judgment or because they “"translate” the Convention standards into standards which are more easily applicable in domestic law'. ${ }^{197}$ So the domestic judges 'often appear to use the Court's case law to supplement, build and refine their own sets of standards, rather than applying them exactly as they have been formulated by the ECtHR'. ${ }^{198}$

\subsection{RUSSIA}

\footnotetext{
${ }^{187}$ Idem.

188 Judgment of the Latvian Constitutional Court, No. 2010-20-0106, 17.02.2011, para. 9 (English translation).

${ }^{189}$ Idem, para. 10.

${ }^{190}$ M. KUJIER, 'Speech: Mechanisms for effective implementation of the European Convention on Human Rights in the Netherlands', 2223.10.2015, Saint-Petersburg.

${ }^{191}$ G. CORSTENS, 'De veranderende constitutionele rol van de rechter', in M. DIAMANT and OTHERs (eds.), The Powers that Be. Op zoek naar nieuwe checks and balances in de verhouding tussen wetgever, bestuur, rechter en media in de veellagige rechtsorde, Wolf Legal Publishers, Oisterwijk 2013, p. 88.

192 J.H. GERARDS, 'The Netherlands: Political Dynamics, Institutional Robustness', in P. PoPELIER, S. LAMBRECHT and K. LEMMENS (eds.) Criticism of the European Court of Human Rights, Intersentia, Cambridge 2016, p. 353, referring to Supreme Court judgment of 20.06.2009, ECLI:NL:HR:2009:BH3079; (GK), No. 36391/02, 27.11.2008.

${ }^{193}$ Idem, p. 353.

${ }^{194}$ Idem, p. 354.

${ }^{195}$ Idem.

${ }^{196}$ Idem, p. 355.

${ }^{197}$ Idem.

${ }^{198}$ Idem.
} 
As was noted in in the introduction (section 1), the Russian Constitutional Court is now permitted by law to establish that a judgment of an international court, including the compensation orders, is not enforceable. ${ }^{199}$ The Constitutional Court renders such a ruling in response to a petition of the executive. $^{200}$

Before the relevant law entered into force, parliamentarians requested the Constitutional Court to declare unconstitutional laws requiring compliance with the Strasbourg judgments. ${ }^{201}$ This request was brought against the background of several new ECtHR judgments that met with criticism in Russia (Konstantin Markin v. Russia ${ }^{202}$ and the two judgments discussed in the following two paragraphs). ${ }^{203}$ In response, the Constitutional Court clarified that Russia does not have to enforce a Strasbourg judgment if this is the only way to avoid violating 'principles and norms of the Constitution' ${ }^{204}$ The said violation can take place, inter alia, if Strasbourg interprets the ECHR differently from what the States Parties agreed to at the time of ratification or if the judgment would violate jus cogens. ${ }^{205}$ Although the Constitutional Court rejected the request, it allowed for the development of a law establishing a mechanism to block the execution of international judgments violating the Constitution. ${ }^{206}$

Upon the creation of the law, the Constitutional Court was asked whether the judgment Anchugov and Gladkov v. Russia, on the disenfranchisement of persons serving a prison sentence, ${ }^{207}$ was enforceable. The Constitutional Court explained that it would reconcile the 'letter and spirit' of the Strasbourg judgment with the Constitution. ${ }^{208}$ It furthermore noted that, because Russia can only ratify treaties that are in conformity with the Constitution, Russia ratified the ECHR in 1998 assuming that the Constitution complied with the ECHR. ${ }^{209}$ Therefore, if the ECtHR adopts an interpretation to which Russia did not consent in 1998 and which would require amending the Constitution, Russia may stick to the ECtHR's interpretation of the Convention from 1998. ${ }^{210}$ Because the ECtHR adopted such an interpretation, Russia could not execute the judgment. ${ }^{211}$

\footnotetext{
${ }^{199}$ Venice COMmission, supra note 11, Appendix, para. 74.

${ }^{200}$ Idem, Appendix, paras. 74-75.

${ }^{201}$ M. AKSENOvA, 'Anchugov and Gladkov is not Enforceable: the Russian Constitutional Court Opines in its First ECtHR Implementation Case', Opinio Juris, 25.04.2016.

202 (GK), 30078/06, 22.03.2012.

${ }^{203}$ L. MÄLKSOO, 'Russia’s Constitutional Court Defies the European Court of Human Rights: Constitutional Court of the Russian Federation Judgment of 14 July 2015, No 21-П/2015’, (2016) 12 European Constitutional Law Review, p. 378-380.

${ }^{203}$ R. HeLGADOTTIR, 'Nonproblematic judicial review: A case study', (2011) 9 International Journal of Constitutional Law, 538, referring to judgment No. 21-П/2015, 14.07.2015.

${ }^{204}$ MÄLKSOO, supra note 206, 381.

${ }^{205}$ Idem.

206 AKSENOVA, supra note 204.

${ }^{207}$ Nos. 11157/04 and 15162/05, 04.07.2013.

${ }^{208}$ VENICE COMMISSION, supra note 11, Appendix, para. 12, referring to the judgment of 19.04.2016, No. 12- П/2016.

${ }^{209}$ Idem, referring to idem.

${ }^{210}$ Idem.

${ }^{211}$ Idem.
} 
The second ruling on the enforceability of an ECtHR judgment concerned the judgment Yukos v. Russia, in which the ECtHR ordered Russia to pay 1.866 billion Euros as just satisfaction. ${ }^{212}$ The Constitutional Court clarified that Russia will only refuse to execute in exceptional circumstances. Such circumstances exist when the ECtHR interprets the ECHR in violation of a general rule of treaty interpretation, 'such as a wholly novel and unsustainable interpretation ..., which departed from the 'jus cogens' principles of treaty interpretation, or was inconsistent with the Convention's object and purpose'. ${ }^{213}$ The court concluded that Russia did not have to pay the just satisfaction, because this would go against certain constitutional principles. ${ }^{214}$

\subsection{SPAIN}

Article 10(2) of the Spanish Constitution requires that the fundamental rights provisions in the Constitution are construed in conformity with the international treaties ratified by Spain. The Constitutional Court has, in connection to this provision, 'underlined the interpretative value of [ECHR] and the [ECtHR] judgments, ${ }^{215}$ and has taken the judgments of the ECtHR into account. ${ }^{216}$ Nevertheless, the Constitutional Court has interpreted this provision as not requiring 'a literal translation' of the ECtHR judgments against Spain, considering that there may be 'normative differences' between the ECHR and the Constitution. ${ }^{217}$ The Constitutional Court, for example, upheld a higher threshold for finding a violation of Article 8 ECHR than the ECtHR in its Lopez Ostra v. Spain judgment. ${ }^{218}$ The Spanish judge therefore retains 'flexibility as to the weight it accords to Strasbourg judgments'. ${ }^{219}$

\subsection{THE UNITED KINGDOM}

The Strasbourg case law is 'not strictly binding', ${ }^{220}$ but the UK Human Rights Act imposes a duty on the domestic judges to 'take into account' relevant Strasbourg judgments against the UK and other States. ${ }^{221}$ This duty was interpreted as a requirement to 'mirror' the Strasbourg approach, ${ }^{222}$ by keeping

\footnotetext{
${ }^{212}$ No. 4902/04. 20.09.2011.

${ }^{213}$ POLAKIEWICZ, supra note 43, referring to judgment of 19.01.2017, No. 1-П/2017.

${ }^{214}$ I. MARCHUK, 'The Tale of Yukos and of the Russian Constitutional Court's Rebellion against the European Court of Human Rights', Osservatoris Costituzionale, Fasc. 1/2017, 16.04.2017, p. 10.

${ }^{215}$ P.J. TENORIO SÁNCHEZ, 'Convergence of the Protection of Fundamental Rights Between the Spanish Constitutional Court and the European Court of Human Rights', in A. RAINER (ed.) The Convergence of the Fundamental Rights Protection in Europe, Springer, Dordrecht 2016, p. 15, referring to judgment $91 / 2000$ as an example.

${ }^{216}$ Idem, 18.

${ }^{217}$ N. KRISCH, 'The Open Architecture of European Human Rights Law’, (2008) 71 The Modern Law Review, 190. The Constitutional Court 'does not make a difference between Convention and jurisprudence', see: Idem, 188.

${ }^{218}$ Idem, 190-191.

${ }^{219}$ Idem, 189; See also: Oxford Pro Bono Publico, supra note 118, p. 66

${ }^{220} R$ v. Special Adjudicator, ex parte Ullah [2004] UKHL 26, para. 20.

${ }^{221}$ R. MASTERMAN, 'United Kingdom', in J.W.A. FLEUREN and J.H. GERARDS (eds.), Implementatie van het EVRM en de uitspraken van het EHRM in de nationale rechtspraak. Een rechtsvergelijkend onderzoek, Radboud Universiteit, Nijmegen 2013, p. 285.

${ }^{222}$ Idem, p. 287; C.C. MuRPHY, 'Human Rights Law and the Challenges of Explicit Judicial Dialogue', Jean Monnet Working Paper 10/12, $18,23$.
} 
'pace with the Strasbourg jurisprudence as it evolves over times: no more, but certainly no less' ${ }^{223}$ Over time, however, the domestic judges moved from the so-called mirror approach, which implied unquestioning acceptance of applicable Strasbourg authority' to accepting 'variance of, and deviation from, the European Court's jurisprudence'.224 Nevertheless, the domestic judges rarely disagree with the ECtHR ${ }^{225}$ and they should have convincing reasons for not following it. ${ }^{226}$ A unanimous Grand Chamber judgment is ‘in itself, a formidable reason for' following Strasbourg. ${ }^{227}$ The UK judges should also follow 'any clear and constant jurisprudence of the Strasbourg court'. ${ }^{228}$ The judges, therefore, should wonder whether the ECtHR has followed an interpretation 'repeatedly in subsequent cases' and thus 'firmly established [the interpretation] in its jurisprudence'. ${ }^{229}$ Special reasons warranting departing from the ECtHR are, ${ }^{230}$ for example, that a judgment lacks 'clarity', is not 'entirely convincing' or does not speak with 'one voice'. ${ }^{231}$ Other such reasons are that 'the ECtHR has misunderstood or been misinformed about some aspect of English law ${ }^{232}$ or that the judges 'have concerns as to whether [an ECtHR judgment] sufficiently appreciates or accommodates particular aspects of [their] domestic process'. ${ }^{233}$ If the judges do not follow Strasbourg, they must give reasons for their decision. ${ }^{234}$

\subsection{UKRAINE}

In 2006, Ukraine adopted the law 'on the Enforcement of Judgments and the Application of the CaseLaw of the [ECtHR]'. This law stipulates that final judgments of the ECtHR that establish a violation in a case against Ukraine are 'binding and subject to enforcement throughout the whole territory of Ukraine pursuant to Article 46 [ECHR]'. ${ }^{235}$ Additionally, the law provides that domestic courts 'shall apply the Convention and the case-law of the [ECtHR] as a source of law'. ${ }^{236}$ There is some uncertainty as to whether domestic judges must also rely on judgments against other states. ${ }^{237}$

\subsection{SUB-CONCLUSION}

\footnotetext{
${ }^{223}$ R v. Special Adjudicator, ex parte Ullah, supra note 223, para. 20; See also: Ambrose v Harris, Procurator Fiscal, Oban (Scotland) [2011] UKSC 43, para. 19.

${ }^{224}$ R. MASTERMAN, ‘The United Kingdom: From Strasbourg Surrogacy Towards a British Bill of Rights?’ in P. POPELIER, S. LAMBRECHT and K. LEMMENS (eds.) Criticism of the European Court of Human Rights, Intersentia, Cambridge 2016, p. 476.

${ }^{225}$ A. DONALD, J. GoRDON and P. LEACH, The UK and the European Court of Human Rights, Equality and Human Rights Commission, Research Report 83, p. 141; KRISCH, supra note 220, 203.

${ }^{226}$ R v. Special Adjudicator, ex parte Ullah, supra note 223, para. 20.

${ }^{227}$ Cadder v. Her Majesty's Advocate (Scotland) [2010] UKSC 43, para. 46 (emphasis added).

${ }^{228} R$ v. Special Adjudicator, ex parte Ullah, supra note 243, para. 20.

${ }^{229}$ Cadder v. Her Majesty's Advocate, supra note 231, paras. 47-48.

${ }^{230} R$ v. Special Adjudicator, ex parte Ullah, supra note 223, para. 20.

${ }^{231}$ M. Amos, 'The Dialogue between the United Kingdom Courts and the European Court of Human Rights', (2012) 61 International and Comparative Law Quarterly, 568; See e.g.: N. v. Secretary of State for the Home Department [2005] UKHL 31, para. 14.

${ }^{232}$ R. v. Lyons [2003] 1 AC 979, 997, para. 46; The ECtHR accepted this reason in Cooper v. UK, No. 48843/99, 16.12.2003, paras. 107, 122126, thus, departing from Morris v. UK, No. 38784/97, 26.02.2002.

${ }^{233} \mathrm{R} v$. Horncastle \& Others, supra note 7, para. 11.

${ }^{234}$ Idem.

${ }^{235}$ Article 2(1) of the said law. An unofficial English translation of the law can be found in: PACE, 'Implementation of judgments of the European Court of Human Rights’, Doc. 11020, 18 September 2006, Appendix III.

${ }^{236}$ Article 17(1) of the said law.

${ }^{237}$ M. GNATOVSKYY, 'Twenty Years of the ECHR in Ukraine’, EJIL: Talk!, 18.09.2017.
} 
The legal boundaries applicable to dialogue with the ECtHR about judgments against one's own state vary widely in the eleven domestic legal systems. In only some States, domestic legislation or case-law spells out that these judgments are binding (Belgium, ${ }^{238}$ Ukraine and Latvia). Therefore, there seems to be little room for dialogue about the judgments. In spite of this requirement, the Latvian Constitutional Court has refused to follow a Strasbourg judgment against Latvia and the Belgian Court of Cassation a judgment against Belgium. ${ }^{239}$ Therefore, the legal requirement to follow judgments adopted against one's own state does, in practice, not imply that there is no room to engage in dialogue with the ECtHR at all. In this connection, it is interesting to recall that the Italian Constitutional Court and the UK Supreme Court first demanded quite a lot of themselves and other domestic judges in terms of following Strasbourg, but then modified their position in order to allow for more room manoeuvre. Apparently, therefore, domestic judges consider it to be important to be able to engage in dialogue, to some extent irrespective of their previous position or more abstract proclamations as to the binding nature of the ECtHR judgments.

In some other States, the highest domestic judges do not consider themselves to be bound to the Strasbourg judgments (Germany and the United Kingdom) or this is laid down in law (Iceland). In these states, it is, from a legal perspective at least, possible to fully engage in dialogue about the judgments against one's own State. Russia goes some steps further, thereby stretching the boundaries to dialogue the most, to the extent that the Constitutional Court is no longer engaging in dialogue according to the Venice Commission. ${ }^{240}$ In Russia, the executive can ask the judiciary to declare that a Strasbourg judgment, including the award of just satisfaction, cannot be executed. In the other states, such a procedure does not exist and the award of just satisfaction does not seem to be the subject of dialogue. Nevertheless, the domestic judges, including the Russian, have expressed their willingness to consider Strasbourg judgments and follow these judgments principle, while still permitting for some exceptions. Moreover, in practice, they usually follow the ECtHR and even try to solve incompatibilities between domestic law and the ECHR as interpreted by the ECtHR, even when they are, legally speaking, not obliged to do so (Germany and Iceland).

The variation in boundaries can also be observed, although comparably less, when looking at the boundaries that apply to engaging in a dialogue about the judgments against other States. Some domestic judges are bound to these judgments (Latvia and previously Italy) or these judgments are probably a source of law (Ukraine). Other domestic judges may take into account the Strasbourg judgments, usually

\footnotetext{
${ }^{238}$ Regarding the concrete dispute.

${ }^{239}$ As described in Vermeire v. Belgium, No. 12849/87, 29.11.1991, para. 25.

${ }^{240}$ As was already noted in the introduction (section 1), see: VENICE COMMISSION, supra note 11, Appendix, paras. $136,146$.
} 
regardless of whether they were issued against their own State ${ }^{241}$ (Austria, Germany, Iceland, Netherlands, Russia and the UK). ${ }^{242}$

More in general it must be observed that, although the legal boundaries indeed vary widely, the practical differences between what the highest domestic judges do with relevant Strasbourg precedents seems to vary less: they generally follow the ECtHR. Additionally, the domestic judges who are legally bound to Strasbourg, still create room for manoeuvre, and domestic judges who are legally not bound to Strasbourg, still usually follow. This finding points to the importance of both dialogue, as many domestic judges want to be able to engage in it, irrespective of domestic prescripts, and of complying with Strasbourg, as it is something many domestic judges want, irrespective of whether they are legally obliged to do so.

When considering more specifically the reasons not to only take a European judgment into account, but also to follow it, this may happen, because interpretation is constant, well-established or clear (Italy and UK) or that a judgment is a pilot (Italy) or Grand Chamber judgment (UK).

The most common and general reason not to follow is that the Strasbourg case-law is incompatible with constitutional fundamental rights or other norms (Germany, Italy, Russia and Spain). More specifically, the domestic judges may find that the ECtHR 'has gone too far'. Going too far includes going beyond what the States accepted when ratifying the ECHR (Austria ${ }^{243}$ and Russia), issuing a judgment that is innovative and/or in conflict with previous judgments (Italy) or defying the general rules of treaty interpretation (Russia). Alternatively, the domestic judges are not convinced by Strasbourg, because of dissenting opinions or because the Grand Chamber has not endorsed an interpretation (Italy). Other reasons to see a judgment as unconvincing is that the ECtHR did not understand (the UK and Italy) or insufficiently accommodated (UK) the domestic system. Furthermore, the domestic judges may invoke the margin of appreciation to diverge from Strasbourg (Latvia) or point to normative differences between themselves and Strasbourg (Spain). Additionally, the domestic judges may consider that they cannot follow Strasbourg, because they are confronted with another context than the ECtHR. The Austrian Constitutional Court, unlike the ECtHR does not consider the ECHR, but also to other constitutional provisions, and the German Federal Constitutional Court has explained that it may have to decide in multipolar situations, whereas the ECtHR looks a case between the applicant and the respondent State. The Italian Constitutional Court reasoned along comparable lines. Also with reference to the different contexts, the domestic judges may not follow Strasbourg precisely, because they engage in a process

\footnotetext{
${ }^{241}$ See also: BODNAR, supra note 53, p. 252: 'In most countries, ECtHR jurisprudence is treated as a whole body of case-law, without distinguishing between judgments having res judicata and res interpretata status'.

${ }^{242}$ See also: CALIGIURI and NAPOLETANO, supra note 88, 156: 'The majority of courts in the Contracting States do not take the view that they are effectively bound by Strasbourg jurisprudence'.

${ }^{243}$ The Austrian Court only mentioned this reason once however, see the Miltner judgment discussed in section 3.1.
} 
adapting the European standards to the specificities of their domestic legal system (Germany and the Netherlands).

A refusal to follow with reference to the constitution, may, however, also be less 'substantially driven'244 and may instead have to do with distribution of powers in the domestic setting. Following Strasbourg may imply amending the constitution or another type of domestic law, which is something that only parliament may be entitled to do, not the judiciary (Austria, Belgium ${ }^{245}$ and the Netherlands). In these circumstances, the hands of domestic courts are tied and they have to wait until the legislature enters the dialogue and takes legislative action.

Regardless of the reason that applies for not following Strasbourg, some judges have clarified that they will motivate a departure from the Strasbourg case-law (Germany and the UK). Not all judges are so vocal however. The Dutch judges may silently apply Strasbourg case-law in a minimal manner, without pointing out that and why they engage in dialogue.

\section{CONCLUSION}

The answers to the questions which boundaries apply to dialogue with the ECtHR from the international legal perspective and from eleven domestic perspectives have already been given in the sub-conclusions in sections 2.4 and 3.12. Therefore, this conclusion will focus on comparing these answers. As was noted in section 1, this comparison makes it possible to see if the ECtHR and the domestic judges speak the same 'language’ when engaging in dialogue.

As for the differences between the two perspectives: the requirement of good faith that features in the international legal system does not feature as such in the domestic systems or the judgments of the domestic judges. Nevertheless, the requirement can be read into the requirement that some domestic judges impose on themselves to reason any disagreement with Strasbourg. An important difference between the international system and several domestic systems is the possibly to rely on domestic law as a justification for failing to follow the ECtHR. The domestic judges are prepared to or allowed to follow the ECtHR, provided they stay within what is permissible under the constitution, whereas the international perspective does not permit invoking domestic law to justify a failure to implement the ECHR. Furthermore, from the international perspective, the State Party that is not a party to a case has comparably more room to engage in dialogue than the respondent State. This distinction is not relevant to each domestic system: the duty that applies when the State is a respondent state may be the same as

\footnotetext{
${ }^{244}$ GERARDS, supra note 195, p. 354.

245 As to execution of Marckx v. Belgium, No. 6833/74, 13.07.1979, the ECtHR 'took the view that it was for the legislature to execute the Marckx judgment', see: E. LAMBERT, The Execution of Judgments of the European Court of Human Rights, Council of Europe Publishing, Strasbourg 2002, p. 8.
} 
when it is a non-respondent State. In short, the boundaries that apply from the international legal perspective and a domestic perspective may differ. This can imply that the domestic systems set boundaries that are more or less strict than the international perspective, as is explained below.

In some domestic systems, the judges seem to have less room for dialogue than the international perspective would permit. This is the case when the judges are bound to the Strasbourg judgments to which their state was not a party, whereas they 'only’ need to take into account such judgments from the international perspective. For these judges, Protocol 16 ECHR will be of particular benefit, because the Protocol enables them to request an advisory opinion, about which they can engage in dialogue, since the advisory opinion is not binding. ${ }^{246}$ Nevertheless, even when, from a legal perspective, there seems to be no or hardly any room for dialogue, the domestic judges may still engage in dialogue with the ECtHR under very exceptional circumstances, meaning that the domestic and international perspectives differ less in practice than on paper.

In other domestic systems, the judges have more room to engage in dialogue than the international perspective envisages. These domestic judges do not consider themselves bound to the Strasbourg judgments against their own State, whilst the international perspective requires that these judgments are executed, including by the judiciary if necessary. This domestic stance implies that the domestic judges may not change their case-law to prevent new violations, not that they obstruct the implementation of individual execution measures. This is only different in Russia, where the domestic judges can even halt the payment of just satisfaction. However, even these domestic judges aim to follow Strasbourg as a rule, meaning that the difference in approach between these domestic judges and the ECtHR will, in practice, not lead to many clashes and have indeed not led to many clashes.

A striking similarity between the international perspective and some domestic perspectives is the existence of the duty to take into account the ECtHR's case-law, which depends on the interpretive authoritativeness of an ECtHR judgment from the international perspective. Moreover, some of the factors that can help establish whether a judgment has interpretive authority, can also be found in the case law of domestic judges. ${ }^{247}$ However, not all the factors that the domestic judge rely on to determine whether they need to take into account the Strasbourg case-law, have something to do with the interpretive authority of a judgment, because some factors depart from the logic of the domestic system. These factors include that the Strasbourg case-law is incompatible with the domestic system, that the ECtHR has gone too far, that the ECtHR did not understand the domestic system or insufficiently accommodated that system and that the domestic judges' hands are tied due to the distribution of powers.

\footnotetext{
${ }^{246}$ Article 5 Protocol 16 ECHR.

${ }^{247}$ Formation, size of the majority, separate opinions, entrenchment and clarity.
} 
Considering the above, it must be concluded that the domestic judges and the ECtHR hardly speak the same language when it comes to defining the boundaries to dialogue. Both perspectives set different boundaries and may define the scope of what is permissible differently. Moreover, even when the two perspectives seem to speak 'the same language', because they both refer to 'taking into account' this does not necessarily mean that they rely on the same factors to determine whether a judgment must be considered. Therefore, clashes are an ever-present possibility. However, it has also already been concluded that the clashes do not happen a lot in practice, due to the willingness of the domestic judges to follow their European counterparts.

Returning to the example in the introduction, the question arises if the difference in how the Russian and British judges' attempts to engage in dialogue have been received, can be explained with reference to the boundaries of the international legal system. Interestingly, the British judges stayed within these boundaries, because they refused to follow the Chamber judgment, before the Grand Chamber adopted its judgment. Due to the referral procedure, the Chamber judgment never became final. ${ }^{248}$ Consequently, the obligation to execute the final judgment never materialized and the British judges could not fail to fulfil this obligation. ${ }^{249}$ The Russian judges, on the contrary, have obstructed fulfilling this obligation. Nevertheless, I do not think that this legal technicality fully explains the difference in reception, since the ECtHR has also accepted that the British judges departed from a judgment that had become final. The ECtHR accepted this, based on the arguments of the domestic judges and the government's clarification of domestic laws. ${ }^{250}$ The ECtHR, therefore, like some domestic judges (as explained in section 3.12) permits room for dialogue, irrespective of the precise legal obligation that the ECHR imposes on the state. Rather, the difference in reception may be explained by the fact that the Russians have created a procedure for not executing individual and general measures on the request of the executive, whereas the UK does not know such a procedure and its judges engage in dialogue about the general measures only. It is relatively hard to know which general measures are required, because their scope is broad and because the ECtHR normally only stipulates individual measures rather precisely. ${ }^{251}$ Therefore, there is more room to engage in dialogue about general than individual measures. The requirement of good faith can also help explain the difference. ${ }^{252}$ The ECtHR seems convinced that the UK judges engaged in a 'bona fide dialogue'. ${ }^{253}$ Therefore, the ECtHR welcomes the dialogue - even when the UK judges would not strictly stay within the international legal boundaries. The involvement of the executive in the case of Russia probably makes it harder to believe that the dialogue is performed in good faith and, therefore, the dialogue is received with little enthusiasm. ${ }^{254}$

\footnotetext{
${ }^{248}$ Article 44 ECHR.

${ }^{249}$ Article 46(1) ECHR.

${ }^{250}$ See: supra note 161.

${ }^{251}$ See section 2.2

${ }^{252}$ See on het importance of the concept of good faith and dialogue: BJORGE, supra note 149, p. 241.

${ }^{253}$ Al-Khawaja and Tahery, supra note 8, Joint partly dissenting and partly concurring opinion of Judges Sajó and Karakaş.

${ }^{254}$ In a different context, the ECtHR described the Russian Government's argument as 'disingenuous', thus implying that the Government is not acting in good faith, see: Berkovich v. Russia, No. 5871/07, 27.04.2018, para. 94.
} 